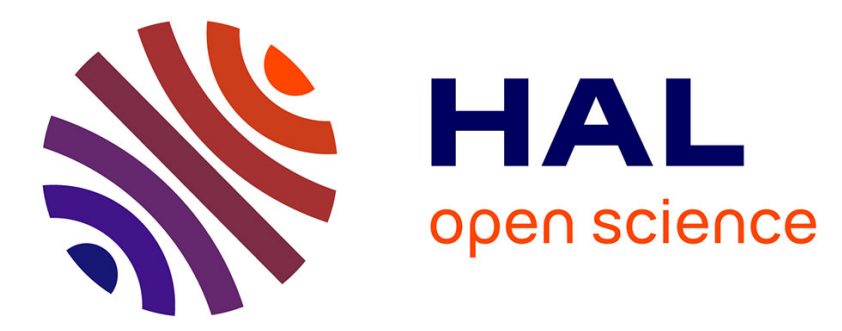

\title{
Factors That Determine or Influence Managerial Innovation in Public Contexts: The Case of Local Performance Management
}

\author{
David Carassus, Christophe Favoreu, Damien Gardey
}

\section{To cite this version:}

David Carassus, Christophe Favoreu, Damien Gardey. Factors That Determine or Influence Managerial Innovation in Public Contexts: The Case of Local Performance Management. Public Organization Review, 2014, 14 (2), pp.245-266. 10.1007/s11115-013-0217-z . hal-02431110

HAL Id: hal-02431110

https: / hal-univ-pau.archives-ouvertes.fr/hal-02431110

Submitted on 9 Dec 2020

HAL is a multi-disciplinary open access archive for the deposit and dissemination of scientific research documents, whether they are published or not. The documents may come from teaching and research institutions in France or abroad, or from public or private research centers.
L'archive ouverte pluridisciplinaire HAL, est destinée au dépôt et à la diffusion de documents scientifiques de niveau recherche, publiés ou non, émanant des établissements d'enseignement et de recherche français ou étrangers, des laboratoires publics ou privés. 


\section{Factors that determine or influence managerial innovation in public contexts: The case of local performance management}

\section{Introduction}

Performance initiatives, and more generally performance-based management (PBM), are widespread in public organizations in western countries today. This development of public management, which at first primarily concerned central administrations and government agencies and then gradually became relatively common in local government as well, expresses a structural movement that is here to stay (OCDE, 2005; Bouckaert \& Halligan, 2008). The adoption of PBM constitutes a break with past practice and represents a major change for local government authorities, in the sense that it (1) concomitantly draws on all the management functions (planning, control, allocation, leadership and budgeting), (2) is characterized by the use of a variety of new management principles and techniques (performance indicators, accountability, management scorecards, etc.), and (3) leads to a radical transformation of behaviors, values, and modes of internal interaction.

There are more and more managerial innovations and modernization initiatives in local government, but there are only a few research studies that specifically analyze the factors that foster the appropriation of these initiatives at the different phases of their introduction and implementation (decision to adopt, adoption and implementation, institutionalization, abandonment or replacement) and which, more generally, study the dynamics of publicsector organizational change (Fernandez \& Rainey, 2006). It would seem that in France in particular, research has focused more on the content of change than on the processes that enable its dissemination (Bartoli, 2009).

The question of the factors that influence of determine managerial innovation is all the more interesting to address in the public sector because, on one hand, the specificities of publicsector organization, functioning and values ${ }^{1}$ suggest conditions of implementation that are distinct from those in the private sector (Birkinshaw \& al. 2008), and, on the other hand, the many PBM initiatives undertaken in Europe show not only high rates of failure or dissatisfaction but also relatively high differences-between countries but also within the same country-regarding the extent of introduction and mastery of these systems of management, thereby justifying an analysis of the factors that influence the dynamic of managerial innovation in public organizations.

Three fundamental questions structure both our conceptual and empirical analysis: What are the factors that influence the dynamic of managerial innovation and the introduction of managerial approaches in the public sector? Do the specific characteristics of public

\footnotetext{
${ }^{1}$ A number of authors (Bryson, 2004; Nutt \& Backoff, 1992) emphasize the fact that the change is much more difficult to conduct in the public sector, because these organizations have a natural propensity towards inertia and resistance. A variety of brakes (structural, cultural, strategic and behavioral (Bartoli, 2009), barriers (Lancer Julnes, 2008) and fragilities can jeopardize change, whether at the initial stage of introduction or during the dissemination and institutionalization stages.

1 Which enables one to eliminate
} 
organizations and of their contexts determine particular conditions of change? Is change in public organizations conditioned and constrained by contextual and environmental factors or could it be the outcome of endogenous initiatives and deliberate actions by the people in charge of these organizations?

The object of this article is thus to conduct an in-depth analysis of the dynamics of innovation in three local authorities via the study of the factors that foster the adoption and implementation of PBM by this type of organization. The theoretical frameworks of organizational change/development, managerial innovation, and public management will serve as a support for this reflection.

We focus on French local authorities, since they present interesting characteristics in the domain of PBM. Indeed, the adoption of this approach has sharply accelerated over the last few years in local administrations, even though no legal or regulatory constraints prescribe its use. The willed, self-driven ${ }^{2}$ initiative of certain local governments and the disparities between them thus pose the fundamental question of the reasons for the different degrees of management innovation in public organizations.

\section{Managerial change and innovation in public contexts}

For public organizations, $\mathrm{PBM}^{3}$ constitutes not only a major managerial innovation but also a vector of organizational, cultural and behavioral change. A number of authors (Damanpour \& Schneider, 2008; Lancer Julnes, 2008; Nystrom \& al., 2002), divide the process of innovation into two distinct phases: initiation, which refers to the adoption of a managerial practice, process or technique that is new to the organization, and implementation, which corresponds to the actual use of the innovation and its integration into existing budgetary and strategic management processes and practices. Performance-based management goes beyond just the measurement of performance. It implies that performance objectives and indicators are the outcome of a strategic analysis and that the information provided informs, in particular, political and managerial decisions (Moynihan, 2006).

Understanding the factors that influence this shift is all the more interesting in the public sector, since the resistances and the brakes-cultural, institutional and organizational-on the introduction of managerial approaches are many. We endeavour to understand not only why certain public organizations are more innovative than others in the domain of management and management control, but also why some are more capable than others in adopting and institutionalizing new modes of organization.

Regarding the determinants of managerial innovation and their relative importance in the public sector, two perspectives or approaches can be identified:

\footnotetext{
2 Which enables one to eliminate normative isomorphism as an explanatory factor in the adoption of PBM.

3 Performance-based management (PBM) is defined as a formal, organized process through which a local authority designs and implements (1) a methodology of reflection and action, (2) a system of intervention and evaluation and (3) methods and principles of action aimed at improving the performance of its public policies and initiatives. PBM is thus a management system that enables public organizations to set objectives and priorities for their development and to manage and organize themselves according to the achievement of results in line with their objectives, and to do so within a context of predefined means and resources.
} 
- The voluntarist or rational perspective: innovation is a rational organizational solution championed by an internal leader aiming to solve a problem or put right an imbalance (Damanpour \& Schneider, 2008; Russaw, 2007).

- The determinist perspective: The environment and the general framework in which the organization operates are considered to be both the main stimulus to and determinant of managerial innovation (Fernandez Alles \& Llamas Schanchez, 2008)

The divergences between these perspectives concern the respective influence of internal and external factors on the dynamic of innovation in public organizations. If, for some authors, external pressures of an institutional or environmental nature and a tendency to isomorphism are determinant (Moynihan, 2004), others, in contrast, focus on more rational considerations such as the existence of clear objectives, the strategy and vision of the managers, and the resources brought into play to explain the shift towards PBM (Lancer Julnes \& Holzer, 2001; Lancer Julnes, 2008). On one hand, then, we find rational and objective motivations (managerial innovation as an organizational solution that enables the correction of imbalances and shortcomings in efficiency and/or effectiveness and thus the attainment of a desired situation), and on the other hand, factors of a political or institutional nature. There is also a total disagreement concerning the respective influence of these groups of factors during the various phases of the innovation process. Thus, according to some authors, recourse to PBM is explained by external determinants such as political or institutional pressure, and it is only during the implementation phase that the role and influence of leaders and managers becomes more pronounced (Moynihan, 2004; Yanh \& Hsieh, 2007). Arguing the opposite view, Lancer Julnes (2008) highlights the importance of technico-rational elements in the decision to adopt PBM and stresses the increasing importance of the role played by politico-cultural factors during the implementation phase. The influence of these categories of factors on the different phases of the innovation process remains, in the end, confused, giving rise to relatively contradictory analyses and conclusions.

The analysis of the determinants of innovation also raises a more fundamental question about the nature of change in the public sector - proactive change versus reactive change, or gradual versus abrupt change-, and, here as well, it reveals an absence of consensus. Given the contradictions and divergences evident in these different perspectives and the shortcomings of the relevant empirical studies, we have chosen to adopt an exploratory approach and a qualitative methodology. We seek to describe and understand the dynamics of change at work in public organizations, and to do so by analyzing the factors that influence the adoption and implementation of local PBM.

\section{Research methodology}

The empirical part of our study is based on an analysis of the process of introducing PBM systems in three French local government authorities: two General Councils ${ }^{4}$, which we will denote as Alpha and Beta, and one town, denoted Gamma. The case-study methodology that we have adopted enables us to shed light on a number of elements that influence

\footnotetext{
4 In France, the General Councils govern the administrative divisions known as "departments". The 101 departments form one of the three levels of local government, together with the 22 metropolitan and 5 overseas regions above them and more than 36,000 communes beneath them.
} 
change processes in public organizations, as well as on the similarities and differences with the private sector. Three factors drove us to favor a qualitative and exploratory methodology, one based on multi-site case studies: the shortcomings and contradictions of the existing theoretical construct, the complexity of the phenomena under study (the analysis of a dynamic of organizational change), and the difficulty in gaining access to data. The exploratory nature of our research leads us to define research objectives and investigation themes that enable us to structure the collection and analysis of empirical $\operatorname{data}^{5}$ (see box below).

\section{Research objectives}

- Analyze and characterize the dynamic of change in public organizations in its various phases of implementation (adoption, institutionalization)

- Analyze and characterize the nature of change in public contexts

\section{Investigation themes}

- Describe and analyze the respective influence of two categories of factors on the decision by local governments to adopt PBM systems: environmental, legal and institutional factors, on one hand, and individual and leadership-related factors on the other

- Describe and characterize the factors (processes and systems) that favor the introduction and institutionalization of PBM systems in local governments

- Describe and characterize the technical and methodological content of change

- Analyze and characterize the willed, self-directed and planned dimension of change in public contexts

We used three types of data collection: documentary analysis, participant observation, and semi-directive interviews. About fifteen interviews, each of from one to three hours in duration, were conducted with a representative panel of operational and functional managers as well as with politicians, using a pre-defined interview guide (see Appendix 1). The guide set out to retrace the history of the development of the PBM initiative in each local government and to identify the main phases of the process and the influence factors (irrespective of whether they promote or impede progress, and whatever their nature).

The methodology used in the collection and analysis of the semi-directive interview data is that of thematic analysis. These processes are derived from the work of Miles \& Huberman (2002), Yin (1994) and Eisenhardt (1989), via the technique of data coding (analysis by grounded theorization).

\footnotetext{
${ }^{5}$ Following Miles \& Huberman (2002), we believe that research that is largely inductive and exploratory does not exclude some preconstructed ideas and choices to do with (1) the content and orientation of the research (the themes for investigation), and (2) the method of conducting these investigations (choice of technique for gathering and analyzing data).
} 
We thus undertook a coding of the interviews (recorded in their entirety and transcribed). The coding was done according to the different influence factors on adoption and development in a managerial innovation initiative, derived from the literature. To crosscheck the information obtained, the choice was made to meet, in the framework of formal interviews in each local authority, all the people involved in the PBM initiative, from its definition to its implementation, and at different levels of the hierarchy, from the councillors to the heads of the functional departments (see Appendix 2). We also conducted a documentary analysis and analyzed the methodological documents related to each of the PBM initiatives studied.

\section{Presentation of the cases studied}

We now present the three cases studied through an analysis of the contextual characteristics of the General Councils Alpha and Beta and the town Gamma (§3.1), and an analysis of the main characteristics of their PBM initiatives (issues and aims) (§3.2), methods of implementation (§3.3), and tools developed (§3.4). The objective pursued, via an analysis of the convergences and divergences between the three cases studied, is to put into perspective, with a view to the qualitative analysis to follow, the endogenous and exogenous factors of adoption and development of a managerial modernization initiative.

\section{1) Context of implementation}

For some authors, public organizations operate within a framework-institutional, political, legal, and economic - that determines their capacity to innovate as well as their dynamic of change (Birkenshaw \& al., 2008; Boyne \& al., 2005).

We now present the indicators of the political, financial, fiscal and demographic context of the three local authorities studied.

Table 1: The financial, fiscal and demographic context of the local authorities studied

\begin{tabular}{|c|c|c|c|c||}
\hline $\begin{array}{c}\text { LOCAL AUTHORITY } \\
\text { STUDIED }\end{array}$ & $\begin{array}{c}\text { CASHFLOW } \\
\text { per } \\
\text { INHABITANT }\end{array}$ & $\begin{array}{c}\text { FISCAL } \\
\text { LEEWAY }\end{array}$ & $\begin{array}{c}\text { POLITICAL } \\
\text { PRESSURE }^{7}\end{array}$ & POPULATION \\
\hline GC Beta & 92 & 0.91 & No & 300,000 \\
\hline GC Alpha & 129 & 0.91 & No & 300,000 \\
\hline Town Gamma & 210 & 1.46 & No & 230,000 \\
\hline
\end{tabular}

Analysis of the contextual indicators of the three local governments shows that they operate in a stable political context. Continuity of political leadership thus appears to be favorable to the creation of an organizational culture capable of change and innovation (Damanpour \& Schneider, 2008; Elenkov \& al., 2005; Kavanagh \& Ashkanasy, 2006).

\footnotetext{
${ }^{6}$ Fiscal leeway $=$ (tax receipts per inhabitant) / (average for bracket or category).

${ }^{7}$ Political pressure assessed according to change in party affiliation of the executive.
} 
In terms of economics, cashflow per inhabitant shows greater financial pressure for the General Councils (GC) Beta and Alpha than it does for the town Gamma. In contrast, fiscal pressure for GC Beta and Alpha is less than it is for the town Gamma. This raises the question of the effect of the economic context on the necessity for managerial innovation and the capacity to carry it out in the local authorities studied (Damanpour \& Schneider, 2008; Walker, 2006).

Finally, we point out that our three local governments, all of substantial size $(230,000$ to 300,000 inhabitants), have financial resources, qualified personnel, technical expertise and significant and diversified knowledge, all supporting a high potential for adoption and implementation of new managerial techniques.

Overall, we can report an absence of any crisis or contextual determinism in the three cases studied. We now continue our analysis with a presentation of the ends, objectives and issues of the PBM initiatives undertaken.

\section{2) Ends, objectives and issues of the three PBM initiatives studied}

An analysis of the documents related to the managerial modernization undertaken by the three local governments studied enabled us to identify their respective ends and issues. We now summarize these elements in the form of a table, then, focusing on similarities and contrasts, we present a synthesis of our analysis.

Table 2: The PBM issues of the three local authorities

\begin{tabular}{|c|c|c|c|}
\hline Ends & GC Alpha & GC Beta & Town Gamma \\
\hline Political & $\begin{array}{l}\text { Improve the } \\
\text { transparency of } \\
\text { public action } \\
\text { Reinforce } \\
\text { democratic } \\
\text { functioning }\end{array}$ & $\begin{array}{l}\text { Improve the } \\
\text { effectiveness of public } \\
\text { policies for citizens }\end{array}$ & $\begin{array}{l}\text { Improve the socio-economic } \\
\text { effectiveness of public policies } \\
\text { for citizens; promote } \\
\text { sustainable development } \\
\text { Provide the means to make } \\
\text { informed decisions, to better } \\
\text { carry out policies, and to give } \\
\text { account of actions in the } \\
\text { name of democratic } \\
\text { communication and } \\
\text { continuous improvement }\end{array}$ \\
\hline Ends & GC Alpha & GC Beta & Town Gamma \\
\hline Public service & $\begin{array}{l}\text { Shift from the role of } \\
\text { Town Councillor to } \\
\text { that of General } \\
\text { Councillor }\end{array}$ & $\begin{array}{l}\text { Improve the quality of } \\
\text { public services }\end{array}$ & $\begin{array}{l}\text { Make public policies more } \\
\text { effective; improve quality of } \\
\text { service for users }\end{array}$ \\
\hline Organizational & $\begin{array}{l}\text { Align expenditure } \\
\text { with priorities and } \\
\text { objectives }\end{array}$ & $\begin{array}{l}\text { Promote cross- } \\
\text { functional cooperation } \\
\text { and the development } \\
\text { of a project and } \\
\text { performance culture via }\end{array}$ & $\begin{array}{l}\text { Reorganize departments, } \\
\text { develop internal processes, } \\
\text { reinforce training, etc. in } \\
\text { order to achieve the ultimate } \\
\text { external objectives }\end{array}$ \\
\hline
\end{tabular}




\begin{tabular}{|c|c|c|c|}
\hline & & $\begin{array}{l}\text { the participation and } \\
\text { contribution of } \\
\text { individuals and } \\
\text { departments to the } \\
\text { collective } \\
\text { implementation of } \\
\text { public policies }\end{array}$ & \\
\hline Human & $\begin{array}{l}\text { Reaffirm the } \\
\text { meaning of all } \\
\text { employees' actions } \\
\text { with a view to } \\
\text { meeting citizens' } \\
\text { needs and } \\
\text { expectations }\end{array}$ & & \\
\hline Financial & $\begin{array}{l}\text { Improve the } \\
\text { effectiveness and } \\
\text { performance of } \\
\text { public initiatives }\end{array}$ & $\begin{array}{l}\text { Control public } \\
\text { expenditure }\end{array}$ & $\begin{array}{l}\text { Increase efficiency of taxpayer } \\
\text { receipts (value for money) }\end{array}$ \\
\hline
\end{tabular}

On the whole, the three PBM initiatives studied pursue comprehensive performance goals with, however, a particular focus on their administrative and political dimensions (rational and efficient use of resources vis-à-vis the delivery of public services, adaptation of public services to environmental needs within the framework of the strategic orientations of the local government). This choice can be explained, firstly, by the adaptation by these local authorities of new management principles derived from New Public Management (NPM) and the Fundamental Law of Finance Laws $(F L F L)^{8}$, and secondly, by the endogenous and exogenous influence factors weighing on local authorities.

The complexity of local PBM initiatives, of an endogenous and exogenous nature, thus derives from a pursuit of comprehensive local government performance in its territorial, public-service, organizational, human and financial components. Having addressed this complexity, we now turn to the methods of managing the three public performance initiatives studied.

\section{3) Methods of adoption and implementation of PBM}

We now present an analysis of the methods of implementation of PBM (launch date, initiating actors, specific management systems) in the three cases studied.

\footnotetext{
${ }^{8}$ The Fundamental Law of Finance Laws (loi organique relative aux lois de finances, LOLF) is a primary lever in the reform of the French State. It has set in motion a process of radical transformation of the State's budgetary and accounting rules. It aims to make public expenditure more democratic and more effective.
} 
Table 3: The methods used to initiate PBM in the three cases studied

\begin{tabular}{|c|c|c|c|}
\hline Method & GC Alpha & GC Beta & Town Gamma \\
\hline Launch date & September 2005 & January 2006 & February 2006 \\
\hline $\begin{array}{c}\text { Actors } \\
\text { initiating the } \\
\text { PBM drive }\end{array}$ & $\begin{array}{l}\text { President of the General } \\
\text { Council }\end{array}$ & $\begin{array}{l}\text { President of the General } \\
\text { Council }\end{array}$ & $\begin{array}{l}\text { Mayor and Secretary } \\
\text { General, acting on proposal } \\
\text { from Deputy General } \\
\text { Manager of Finance and } \\
\text { Accounting }\end{array}$ \\
\hline $\begin{array}{l}\text { Management } \\
\text { systems }\end{array}$ & $\begin{array}{l}\text { - High involvement of } \\
\text { councillors in the PBM } \\
\text { initiative, especially in } \\
\text { the definition and } \\
\text { evaluation of the } \\
\text { political orientations. } \\
\text { - High involvement of } \\
\text { senior leadership and } \\
\text { functional departments } \\
\text { in the definition of the } \\
\text { initiative and in its } \\
\text { implementation. } \\
\text { - Setting up of an } \\
\text { internal control and } \\
\text { coordination office to } \\
\text { manage the initiative. } \\
\text { - Organization of sub- } \\
\text { projects; break down } \\
\text { into phases, planning of } \\
\text { work by work groups. }\end{array}$ & $\begin{array}{l}\text { - Participatory and iterative } \\
\text { approach: } \\
\text {. between councillors, senior } \\
\text { management and project } \\
\text { heads in the definition, } \\
\text { leadership and follow-up of the } \\
\text { project; } \\
\text {. between the senior } \\
\text { leadership and the operational } \\
\text { leaders and heads of the } \\
\text { programs (definition of } \\
\text { strategic and operational } \\
\text { objectives); } \\
\text {. between the operational } \\
\text { and functional leadership or } \\
\text { heads of the programs (project } \\
\text { follow-up: budgetary follow- } \\
\text { up, follow-up of relevant } \\
\text { indicators). } \\
\text { - Elaboration of decision- } \\
\text { support information system } \\
\text { (DSIS). }\end{array}$ & $\begin{array}{l}\text { - Support and facilitation of } \\
\text { the initiative by councillors } \\
\text { via the resources manager, } \\
\text { the political referent of the } \\
\text { project. } \\
\text { - Management of the } \\
\text { project by the Deputy } \\
\text { Finance and Accounting } \\
\text { Manager and by the } \\
\text { initiative's Project Manager, } \\
\text { supported by the town's } \\
\text { Secretary General. } \\
\text { - Setting up of cross- } \\
\text { functional work groups } \\
\text { (functional and professional } \\
\text { leadership teams) in the } \\
\text { implementation of the PBM } \\
\text { initiative. } \\
\text { - Appointment of } \\
\text { administrative and financial } \\
\text { referents to the professional } \\
\text { leadership teams ensures } \\
\text { follow-up of the } \\
\text { performance initiative at the } \\
\text { operational level. }\end{array}$ \\
\hline
\end{tabular}

According to the theory of managing a local performance-based initiative, the successful management of such a project is based on the participation and involvement of all organizational actors in the pursuit of collective objectives. It thus has to be managed at a strategic level by the councillors, and coordinated at the administrative and operational level by the senior management teams. If GC Alpha did indeed integrate all local actors in its performance project, the relevant personnel were not involved in the projects of GC Beta and Town Gamma. This appears to reveal a cultural resistance to change, and it could constitute an obstacle to the development of PBM in the public sector.

We can also highlight, in the three cases studied, the setting up of formal systems for managing the performance initiative, demonstrating the high level of resources and means 
mobilized, as well as the respect for the rhythm of learning specific to a management-byresults approach.

\section{4) The managerial innovation tools developed in the three cases studied}

Here we undertake an analysis of the three main tools of local PBM. Adopting a sequential approach, we begin with the first of them, the planning tools.

\subsection{1) An analysis of the planning tools}

In theory, strategic and budgetary planning should lead, in an incremental process, to the realization of four stages: the strategic diagnosis, the strategic segmentation, the reorganization of the budgetary architecture, and the realization of an annual management plan (or annual performance plan, APP). These planning tools must also, in a comprehensive and integrative vision of organizational management, be of a political and operational nature. When it comes to respecting these theoretical principles of local PBM, however, we can observe a number of disparities between the local authorities studied.

Concerning the strategic diagnosis, the local authorities' public-policy management practices show that there is no standard, universal approach and that, on the contrary, the contextual variables (weight of history, socio-economic context, local identity, specific needs and expectations) play a major shaping role. Within the three local authorities studied, then, a strategic diagnosis was conducted that oriented the definition of the strategic segmentation, defined as the gradual and sequential drawing out of the authority's general development orientations and objectives around a Missions-Programs-Actions scheme (MPA).

Concerning budgetary architecture in an MPA scheme, the life of a local authority is punctuated by budgetary procedures: the debate on budgetary orientations (DBO), the vote on the initial budget ${ }^{9}$ (IB), on modifications to the budget (MB) on the supplementary budget (SM), and on the administrative account (AA). It is through this budgetary process that the effectiveness of public management is expressed, and thus any reform of local public management would entail a revision of these procedures. The method used in the three local PBM initiatives under study, then, consisted in modifying the budgetary process at each of its stages (DBO, AA, IB) in order to enable the councillors to exercise their executive role. Nevertheless, in practice, the characteristics and use of these segmentations qualify their theoretical goals. Moreover, the existence within GC Alpha, GC Beta and town Gamma of support missions and programs reveals the non-allocation of administrative expenses to public policy costs. The budgetary practice of GC Beta does, however, show that the implementation of cost accounting and/or activity-based accounting can enable the allocation of these indirect costs to the operational programs.

Concerning the definition and formalization of strategic objectives, Alpha, Beta and Gamma all elaborated scorecards of the APP-type. Nevertheless, if the APP are presented during the

\footnotetext{
${ }^{9}$ In French local finance, the initial budget (budget primitif) is the budget voted by the local assembly at the start of the fiscal year. It sets the sum of money available for expenditure over the year, and estimates the amount of tax receipts expected.
} 
IB vote, their real impact on decision-making is open to question, as much for the adaptation of means to public policies as for the reorientation of these policies.

\subsection{2) An analysis of accountability tools}

From a theoretical perspective, according to Toulouse (2007), good governance requires actors who are accountable: accountable for their choices and decisions, accountable for resources and results. Thus, the accountability derived from local government's new managerial practices, in line with the logic of translating strategic plans into operational plans, must be top-down and must be extended to all dimensions of the organization: political, administrative and individual.

Empirically, from an analysis of the accountability practices of Alpha, Beta and Gamma, we note that only the Alpha set up real accountability tools for all local actors:

- The councillors, by reorganizing the political commissions around missions and by naming them "political" program managers;

- The administrative personnel, by reorganizing the deputy senior management teams around missions and the departments around programs, and by naming "administrative" program managers;

- The employees, by translating strategic objectives into operational objectives, and by making performance the focus of the annual appraisal review.

To conclude our study of the PBM tools used by the local authorities under study, we now make a comparative analysis of the evaluation tools.

\subsection{3) An analysis of the evaluation tools}

Concerning the evaluation systems, only GC Alpha and town Gamma elaborated real Annual Management Reports (AMR), presented during the AA vote. Nevertheless, all three authorities have extended the range of their management control tools beyond purely financial indicators, developing indicators to measure organizational efficiency, quality of service and territorial impact, all related to the administration's strategic objectives. Our analysis of the tools deployed in these three PBM initiatives leads us to emphasize, firstly, the importance of the political and administrative leaders' involvement in the implementation of the initiative, and secondly, the high degree of formalization and methodological definition associated with that implementation.

Having presented the three PBM initiatives, we now draw on them to make a qualitative analysis of the factors that influence managerial innovation.

\section{Analysis of the dynamic of innovation and the factors that influence its development}

To meet our research objectives-to analyze and characterize the dynamic of change in public organizations at its different phases of implementation-we now undertake a qualitative analysis of the factors that promote adoption, introduction and institutionalization of a local PBM initiative. 


\subsection{Factors that promote adoption}

The case studies show that recourse to this type of initiative does not constitute a response to an economic or financial crisis suffered by the local authorities but, on the contrary, takes place in a relatively stable political, economic and financial context. These initiatives are often presented as appropriate or optimal responses to the problem of financing public policies, a problem that increasingly affects all local governments. In the three cases studied, the adoption of performance initiatives is part of a drive to rationalize and optimize public spending; it is a proactive response to an increasingly complex and uncertain budgetary context. Whoever one questions in the three local authorities, the PBM initiative is presented as a set of technical instruments employed in the pursuit of not only greater efficiency, but also greater accountability, particularly of the political actors ${ }^{10}$.

"We delayed by one year our running into an impasse-from late 2010-early 2011, as we had initially forecast, to late 2011-early 2012-but we're heading there for sure, because the burden of the social contributions we have to pay is so great that we will not make it... At any rate, we had to make people aware, mobilize them, and make them take responsibility. And one of the tools that seemed most useful was the FLFL, that was why we recommended it to the President of General Council at the time; it happened like that, we had in mind what the FLFL can contribute culturally to making public spending more responsible." (GC Alpha).

If, as we have pointed out, the initiatives studied were not undertaken after the outbreak of a major crisis impacting the territory or institution, the actors questioned, in contrast, emphasized that the anticipation of a crisis and the difficulties in taking on new responsibilities following the enlargement of the scope of their responsibilities was, firstly, a powerful factor in making their teams aware of the need for change, and secondly, in making them accept the initiative. For one of the local authorities (GC Alpha), it was the perception of a future risk arising from the specific evolution of the demographic structure of the department that explains the realization of the need to do something and hence the adoption of PBM. According to a number of actors questioned, this realization was not immediate, but was the outcome of a long evolution that gradually modified behavior and attitudes toward not only the management of public expenditure but also a number of managerial concepts such as effectiveness and performance. This evolution results from the common perception of a serious incompatibility between three elements that structure local management, namely the continuous increase in responsibility and public spending, the traditional methods of financing via debt, and the increased scarcity of tax revenue. This cultural change, which finds expression in councillors and administrators via their appropriation of the values and principles associated with the pursuit of performance and results, is cited in each of the three cases as an indispensable precondition for the adoption of such initiatives. For one of the local authorities (GC Beta), a near-bankruptcy situation in the 1990s, related to overinvestment, kick-started this transformation of the representations and values of public policy management. For another (GC Alpha), prior experimental use of management control tools such as cost accounting facilitated the gradual appropriation by managers and employees of a performance rationale.

\footnotetext{
${ }^{10}$ And this irrespective of the category questioned within a given local authority: operational and functional managers, whether from finance or not.
} 
"No, I did not say we were suddenly ready to take tools from the private sector. It's more that everybody be aware that when resources are limited and things still need to be done, you have to try to do them with fewer resources. If we didn't have any problem with resources, we wouldn't ask ourselves how we could do better with less. This awareness has taken place before, but not fifteen years ago." (GC Beta).

"We obviously have problems financing our public policies. We absolutely have to be more effective, there's no other choice, it's essential. We cannot continue to do what the State used to do, for example in National Education: there's a problem, hire more employees. That way of thinking has to stop; we have to start using the tools we have. We must not hesitate to evaluate the resources we mobilize and adopt the private sector's mantra, the ratio of quality to cost. Here, we know how to produce quality but nobody has any notion of cost" (town Gamma).

For the majority of actors interviewed, these initiatives are seen as tools to rationalize strategic and political choices, facilitating the definition and formalization of the issues and the setting of financial and action priorities. The reforms undertaken at a national level and the determination to no longer address problems from only a quantitative standpoint (by providing additional resources) but rather according to the principles of rational resource allocation, these are the reasons put forward for recourse to PBM.

The desire to embrace innovative practices initiated at the national level via the FLFL also constitutes a motive for the adoption of PBM (for all three local authorities). The actors interviewed evoke the risk of being left behind and appearing as laggards compared to the central administration, in particular as regards the evaluation and segmentation of public policies. In two of the three local authorities, the politicians had been involved in the elaboration and implementation of the FLFL at the national level. Moreover, one of them, thanks to his profession (chartered accountant), was very well versed in everything that touched on PBM, the use of indicators and the rationalization of expenditure.

"It has to be said, of course, that our President, Mr. X, who at the time was not President but 'only' Vice-President of the GC, is one of the founding fathers of the FLFL. So it was inevitable that we would go that route; that was the impetus for our decision to go for it, in late 2005" (CG Alpha).

"It is obvious that we wanted to jump on the bandwagon of reforms that the State is implementing. Frankly, as far as I can see, the way the State is evolving is exemplary, and the local authorities are far, far behind. Even we who, amongst the biggest local authorities, decided earliest to hop on the FLFL bandwagon, we are still far, far behind in implementing what the State has already implemented" (town Gamma).

In all three cases, political initiative and impetus were critical in the decision to adopt PBM. For the two general councils, we can highlight the identification of the presidents with these innovations and their consistent championing of the projects. In these cases, the adoption of PBM is clearly the outcome of an individual political will and initiative, more than of the direct pressure of events or the economico-financial context. This high level of involvement seems to have been a key factor in mobilizing the administrative sphere by lending credibility and legitimacy to the initiative. The use of forward-looking financial thinking, emphasizing the budgetary and economic risks threatening the local government, and the 
definition of a vision of development highlighting the gap between future projections and the present, thus creating a sense of dissatisfaction, are means used by the politicians to mobilize their teams in the service of the performance initiative. The dissatisfaction engendered in turn facilitated the acceptance of the initiative internally and was perceived as a positive force for change and internal mobilization.

"You need one hell of a locomotive! The initiative is really a freight train, so, to get it going, you need enormous tractive force at the beginning, a force capable of creating sufficient inertia to ensure that the movement cannot be stopped. So, in this connection, President $X$ is not just a locomotive, but a whole train of locomotives! The President is very committed to this project; he made it clear from the beginning, he explained why... Given that fact, the employees knew where they were going, and they knew why... In local authorities where such initiatives are not regularly promoted by the politicians, it's like Agenda 21, it's just lip service. Here, we're not just paying lip service, we're taking action" GC Beta).

"I think he alone is the driving force of the whole project. There is no political will outside of him, even if afterwards some have also gotten into it, and many others a little less. He is really at the origin of it. Together with Mr. X, they are the most highly involved General Council Presidents in France. Indeed, the sponsor of such a project is rarely a politician. It's still very unusual. What's certain is that when you have the biggest boss as manager, it's easier to get things rolling and make changes" (GC Beta).

"You first have to give the vision, the institutional objectives. This is what the Mayor of Gamma wants for his town over the next five years. In five years, when you take a snapshot, the Mayor can already say: 'There, this is what I want, this is what I want the town to look like'. But before that, before the vision, you have to know how to create dissatisfaction. You create dissatisfaction, you communicate a vision and then you take the first steps. If those three elements are not in place, you will never be able to overcome resistance to change.." (town Gamma).

Finally, we note that the interviews show the importance of the symbolic dimension of management tools. In the three cases, the PBM initiatives function as a means to give evidence of sound, rational management to the outside world, to citizens and observers. The determination to catch up to the State in this domain and the desire to appear particularly innovative in the management of public policies compared to other local authorities is, as we've seen, preponderant (two out of the three cases). A rationale of emulation, normativeness and the pursuit of external legitimacy are thus complementary sources motivating the adoption of these managerial techniques.

"So, there was a notion of control and a notion of transparency, so that people may understand why we levy so much tax. That was the basis of it, for him. I think the President, Mr. $X$, accepted the rationale of the FLFL by saying to himself, 'it is not only an internal rationale, but one that is aimed at the whole population of residents. It should motivate every resident to go and vote, because it is also a way of saying that the department has a reason for living, its functioning has been optimized and it is investing" (GC Alpha).

There is thus a plurality of motivations and issues associated with PBM (effectiveness and efficiency of spending, readability and visibility of public initiatives, image) which seem to combine in such a way that at a given moment, the decision is made to undertake such an 
initiative. Having analyzed the factors that influence the adoption of PBM initiatives, we now turn our attention to the internal vectors of implementation and institutionalization.

\subsection{Factors that promote the implementation and institutionalization of the PBM initiative}

Involvement of the highest-level politicians is, as the three cases show, a decisive element in the adoption and gradual extension of the PBM initiative. The personal involvement of politicians, their identification with a projectthat they have initiated and sponsored, is cited as a determining factor of legitimation and acceptance by the different stakeholders (senior technical and operational management teams, functional teams). This constant political mobilization is seen as a guarantee of a sustainable, long-term commitment to the new mode of management and new budgetary architecture, and it reassured the different actors involved.

"It's essential. If the President of the GC was not himself convinced, things would be very difficult. You have to put yourself in the shoes of the politicians. There is only one thing that could derail us, and that is that X quits the GC. That would kill the project. But with him in the GC, and what's more, now taking office as President, I have no doubts at all" (GC Beta).

"I think there, in all honesty, the answer is X. He has never let up the pressure. He set a course by saying, 'Next year we work like this; we will present the budget in this way. It's what I want, it's very important to me' (GC Alpha).

In the three cases, the efforts by the politicians and the project managers to make everyone aware of the rationale of PBM were decisive. The interviews show the importance of this form of leadership, the effects of which are more pronounced during the implementation and extension phase of the initiative. This technical or methodological leadership aims to define the stages and methods of work, to clarify and assign responsibilities, and to coordinate action. The technico-administrative manager is presented as an essential intermediary between the managers and the politicians. A clear and pre-established distribution of roles, especially between politicians and employees, is often presented as a factor favoring the commitment of managers and employees. This was all the more important in that the introduction of PBM was accompanied in all three cases by an overhaul of the organization charts, structures and managerial responsibilities between the departments and senior management teams, giving rise to a number of fears and reservations among managers and employees. Even if, prior to the project, there was an organizational climate that favored this type of initiative, the actions of the project managers (the technical leaders) contributed to maintaining and reinforcing it, and promoted a gradual organizational appropriation of the project ${ }^{11}$.

"As everyone was under pressure, and a healthy pressure (in the sense that it wasn't a 'due yesterday' situation; there were teams that had done all the preparatory work, the segmentation. The employees were all mobilized around $X$, the project manager... There was

\footnotetext{
${ }^{11}$ Especially via their communication actions, their efforts aimed at promoting participation, and the time they spent explaining things to the different levels of management and employees. For example, for GC Alpha, this communication/participation took the form of internal opinion surveys (a 70\% response rate), interviews, and meetings to dialogue with and brief employees (a $90 \%$ participation rate).
} 
a consulting firm to accompany us, to do the back-office work and to make sure that from a methodological point of view nothing had been forgotten, but it was not them who were on the frontlines" (GC Alpha).

"Mr. X (the project manager) needed a dedicated structure, because that was essential to get the administrative machine rolling. I see it in the network of people I work with, those who do not have a dedicated structure, when they launch something that is not very strong, addressed to either a hyper-present Director General of Services ${ }^{12}$ or to politicians who can stir people into action, well, in that case 'the machine stalls'; frankly that's the expression for it. Working within the dedicated structure of Mr. X, then, seems totally necessary to me, all the more so as today we have this commission of politicians." (GC Alpha).

The case studies also show the importance of a formalized methodological framework and organizational structure. The definition of work rules and methods, the delimitation of the roles and responsibilities of each organizational constituent, and the organization in time of the different phases of the strategic process are thus decisive in giving meaning and coherence to a process that disrupts or throws into question internal arrangements, responsibilities and ways of working. The methodological rigour and formalization and the accompaniment by a dedicated unit or consulting firm are presented in the three cases as a key element in ensuring that employees and operational managers "buy into" the initiative. For two of the local authorities studied, the phase of defining work procedures and methods lasted more than a year, and it enabled the existing institutions and services to position themselves (relative to each other) within this new system. Moreover, the methodological rigor was seen as lending credibility to the initiative in the eyes of local groups and institutions. Finally, for the actors interviewed, a thorough communication initiative, bearing as much on the content of the changes being made (the objectives and results expected) as on the accompaniment structures and implementation system, turned out to be a critical success factor.

"Among the managers of different ages, there was a 'buying into' the project. Not always immediate, spontaneous or $100 \%$, but, on the whole, the managers committed to the initiative and 'sold' it to their teams. They 'sold' it because they found themselves with a clearer way of working, a positioning of the politicians that suited them better: everybody had their role and the roles were perfectly coordinated with each other, so there was no reason for anyone to step on others' territory. This participatory, gradual approach then fostered an acculturation of the employees and now we are sure of continuity, of a generalization of the initiative" (GC Beta).

"We took all of 2005 to work things out. The idea was to focus on methodology. We were not locked into a timetable, or obsessed with the results to be achieved, but we did have a method: procedures, declarative minutes, necessity for a technical committee (senior management team) and a management committee (finance commission). To ensure an acculturation of the approach, one must see to it that the institutions that exist work for this

\footnotetext{
12 In French local authorities, the Directeur général des services assures the general coordination of services for the implementation of decisions. He/she contributes his/her administrative, financial and legal expertise to the definition of strategic objectives and the elaboration of local projects.
} 
new approach. All of this had to be written up and explained: that's what our launch document did" (GC Alpha).

In light of our analysis of the case studies, we now draw out certain general lessons about the factors influencing the adoption and introduction of a PBM initiative.

\section{Lessons learned from the case studies}

Analysis of the factors influencing and determining the dynamic of innovation shows the necessity of distinguishing two phases of innovation: that of adoption and that of implementation ${ }^{13}$. Corresponding to each phase are two categories of influence factors: the factors that directly trigger the decision to resort to managerial innovation (triggering factors), and the factors at work in the actual implementation of the process that contribute to the acceptance and appropriation of the innovation by the local authorities (implementation factors). On this point, out results confirm those of a number of authors, including Damanpour \& Schneider (2006, 2008), Lancer Julnes (2008), and Johansson \& Siverbo, (2009), who all stress the importance of making distinctions between the various phases in the public-sector innovation process.

Moreover, the type of factor and its degree of influence varies according to the phase considered. While the political leadership, institutional and technico-rational factors play a relatively important role during the adoption phase, in the implementation phase it is the methodological and administrative-style leadership factors that are preponderant. Institutional motivations as much as technico-rational factors seem to explain the adoption by local authorities of a managerial innovation such as PBM. Thus, if an emulative or symbolic rationale guides each of the three local authorities studied in their PBM initiative, the initiative is also seen as a technique to solve problems of public-sector efficiency and effectiveness. This finding contradicts the studies and approaches that affirm that the rationale for management in public organizations has more to do with image and the pursuit of public legitimacy than a real, objective need. Our research, in contrast, concomitantly validates the two theoretical perspectives that contradict each other regarding the sources and determinants of organizational change, namely institutionalist theory (DiMaggio \& Powell, 1983) and the rational adaptive theories (Burke, 2002; Scott, 2001). Our study also reveals the existence of a third category of factors, "favorable environments", which constitute necessary but not sufficient elements for the emergence and development of managerial innovation.

We now present our findings on (1) the importance of the commitment of local political and administrative actors; (2) the necessity for willed, self-directed, planned change that

\footnotetext{
${ }^{13}$ Our case studies enable us to demonstrate and to distinguish the triggering factors favorable to the initiation and implementation of change, and in particular the elements that intervene positively once the process has been launched. We thus find again Bartoli's (2009) typology, which identifies the incentives to change within public organizations and the sustainable factors and their associated representations.
} 
proceeds incrementally, and (3) the influence of favorable environments in the adoption and implementation of local PBM initiatives.

\subsection{The importance of the commitment of the political and administrative leaders}

Whatever the phase considered, the human element and the role of leaders as agents of change are fundamental. Our study highlights, in particular, the different-but equally fundamental-influence of two forms of leadership, one political, the other more technical and administrative.

Leadership of the political type (as understood by Nutt \& Backoff, 1992) promotes and legitimizes the change initiative among the actors concerned. Continuous, sustained involvement by the politicians plays a decisive role in assuring the involvement of other actors at different levels of the organization ${ }^{14}$; it conveys the message that innovation is here to stay and that all necessary resources and means will be mobilized and allocated ${ }^{15}$. This sponsorship function, which is decisive during the launch phase of the initiative, remains important during the implementation phase.

Accompaniment, supervision and training in methodology are the roles played by technical leadership. Indeed, the head of the technical team is a key actor in the change process, which he/she accompanies and facilitates through sustained leadership and mobilization of all relevant actors. Moreover, he/she occupies a central position, acting as an interface between the politicians and the employees, promoting dialogue and coordination between them. The technical and administrative leaders, via their relational and communication management, thus play a key role in installing the performance initiative in its internal social and political context. This finding confirms that, in particular, of Maurel (2006), Burke, (2002) and Fernandez \& Rainey, (2006) on the importance of involvement, dialogue and negotiation in the conduct of innovation and change strategies in public organizations. These results also confirm those of other studies (Charih \& Paquin, 1993; Bryson \& Roering, 1988; Maurel, 2006) that highlight, in public organizations or administrations, the importance of the groups and individuals in charge of the technical and administrative management of the change process. More imperative than in the private sector, in the public sector the necessity of explaining change ${ }^{16}$, of communicating its characteristics, effects and contributions, of involving relevant actors and of overcoming resistance and prejudices as regards culture and values justifies the key role played by this type of leadership in the dynamic of change. $\mathrm{His} /$ her action is thus situated downstream from, and is complementary to, that of the political leader. The many brakes ${ }^{17}$ and resistances to change, which according to certain

\footnotetext{
${ }^{14}$ Especially other politicians.

${ }^{15}$ This is all the more important in that, given the proclivity of private-sector organizations to get caught up in management fads, the implementation of this type of initiative in the public sector creates defiance among managers and employees.

${ }^{16}$ Especially when change is based on techniques and concepts derived from the private sector.

17 Of a cultural, behavioral, strategic or structural nature.
} 
authors (Bartoli, 2009; Bryson, 2004) characterize the public sector, would explain the necessity for this dual impetus and leadership in the management of change and the importance of socio-political and relational management.

The case studies also confirm the importance of the managerial system and the resources dedicated specifically to the implementation of PBM. This finding is in line with those of Kemp \& al. (1993), Boyne \& al. (2005) and Fernandez \& Rayney (2006), which confirm that the mobilization of substantial resources constitutes the major success factor for change in the public sector.

\subsection{Willed, self-directed, planned incremental change}

The case studies also show that the adoption of PBM is an expression of willed, self-directed change, not change that is forced or imposed by contextual pressures (such as a financial crisis). It is above all a planned change, and one that is incremental. Allowing time for experimentation, learning, communication and understanding of the issues is a key element in the process of organizational acceptance and appropriation. In the three cases, more than a year was devoted to the phase of methodological design and preparation, and it involved many meetings and briefings. Furthermore, the transformation of behavior and organizational routines took place over several years. What we see, then, is a combination of planned and prescribed change and emergent and constructed change that enables the actors involved to understand, analyze and experiment with the proposed changes and to modify their behavior accordingly. Of the two opposing views of the appropriate rhythm of change in the public sector, adaptive, incremental change versus drastic, wide-ranging change (Balogun \& Hope Hailey, 2008), our research confirms the first approach. In line with what Maurel (2006) described regarding the introduction of cost accounting in the general councils, the processes of change observed in our three cases are dynamic but non-linear, and they take place in "small steps" (as understood by Lindblom, 1968).

\subsection{The environments favorable to managerial innovation}

The case studies show that it is necessary to dissociate the triggering factors per se from the elements that contribute to the construction of a favorable environment. If the former constitute objective facts that constrain and legitimate the definition of a strategy for change, the latter appear to be factors whose presence is essential if the performance initiative is to have a chance of succeeding. In the first case, the triggering factors function as an incentive to change and thus constitute a necessary but not sufficient condition for success. In the second case, the favorable environment determines the actual possibilities for change and the effective introduction of strategic processes (no condition necessary).

In the local authorities studied, the development of an environment favorable to the introduction of PBM is the result of a cultural change that finds expression as a collective will or inclination to change, as well as of a positive perception of management and performance. Past difficulties together with the actions of leaders (political leaders in particular) have a decisive effect on this cultural transformation. 
We summarize our findings regarding the factors that influence public-sector managerial innovation in Figure 1, below. 
Figure 1: The factors that influence managerial innovation in the local public sector

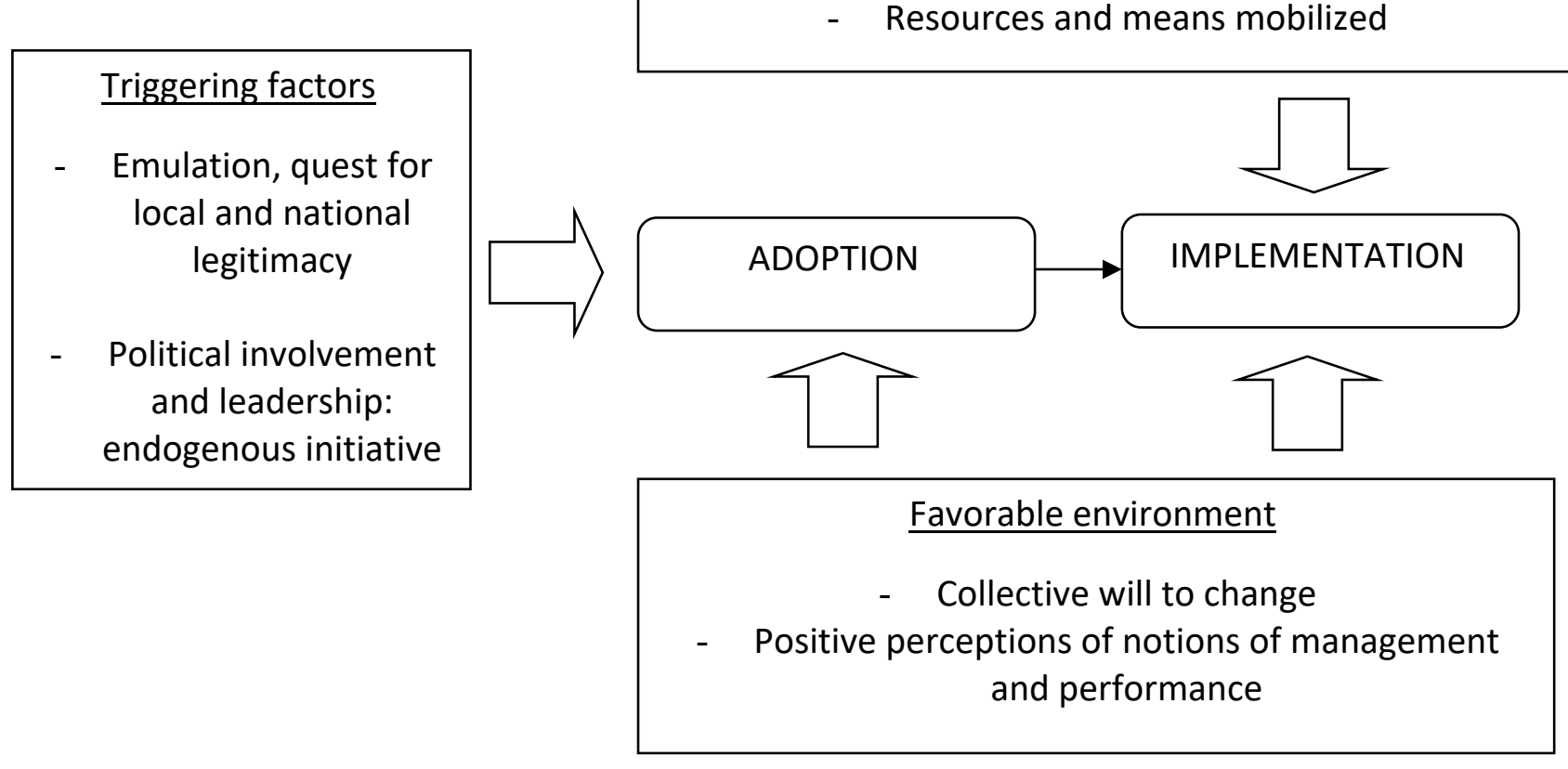

\section{$\underline{\text { Triggering factors }}$}

- Emulation, quest for ocal and national legitimacy and leadership: endogenous initiative

\section{$\underline{\text { Development factors }}$}

- Administrative commitment and leadership

- Political support

- Organizational and methodological system

- Resources and means mobilized

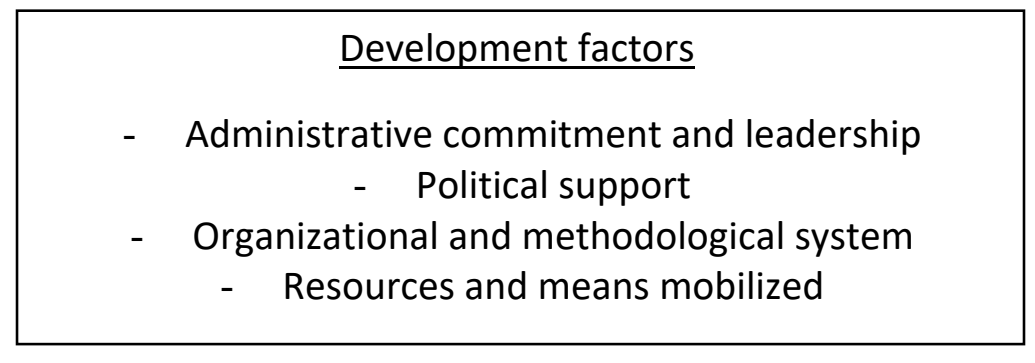

\section{Favorable environment}

Collective will to change and performance

\section{Conclusion}

The object of this article was to conduct an in-depth analysis of the dynamic of innovation in three local authorities via a study of the factors that favor the adoption and implementation of PBM in public-sector organizations. Among the theoretical frameworks referred toorganizational change/development, managerial innovation, and public management-we demonstrate a tendency to overestimate the explanatory power of the neo-institutionalist theories. Indeed, our analysis illustrates a balanced vision of the human, technical and contextual factors at the origin of this type of managerial innovation. Moreover, it also highlights the difference in added value of these categories of factors for the adoption and implementation of such initiatives. Our view, then, is that the adoption of management techniques in the public sector cannot be reduced to a simple quest for institutional legitimacy.

Furthermore, the specific characteristics of public organizations and their context would seem to determine particular conditions of change. Indeed, the implementation phase is much longer in the public sector, for reasons to do with, in particular, the need to legitimate, explain, train and foster participation. As the brakes on change can be strong, since the culture of public actors does not lend itself directly to the introduction of managerial innovation, the organizational and methodological systems implemented, as well as the management of the change process itself, are critical factors in the success of this type of 
initiative. Together with the political support that enables the championing and dissemination of such managerial innovation in public organizations, a PBM initiative can support managerial, political and administrative decision-making at both the operational and administrative level, enabling the organization to meet the challenges of the turbulence and tension that characterize the current public-sector context. 


\section{References}

Balogun J., Hope Hailey V., (2008), Exploring Strategic Change, Prentice Hall, London.

Bartoli A. (2009), Management dans les organisations publiques, Dunod, $3^{\text {ème }}$ édition.

Birkinshaw J., Hamel G., Mol MJ. (2008), « Management Innovation », Academy of Management Review, Vol. 33, Issue 4, p. 825-845.

Bouckaert G., Halligan H. (2008), Managing Performance- International Comparisons, Routledge.

Boyne G. A., Gould-Williams J. S., Law J., Walker R.M. (2005), " Explaining the Adoption of Innovation: An Empirical Analysis of Public Management Reform », Environment and Planning: Government and Policy, Vol. 23, Issue 3, p. 419-435.

Bryson J.M., Roering W.D. (1988), "Initiation of Strategic Planning by Governments", Public Administration Review, Vol. 48, Issue 6, p. 995-1004.

Bryson, J. M. (2004), Strategic Planning for Public and Nonprofit Organizations: A Guide to Strengthening and Sustaining Organizational Achievement, San Francisco: Jossey-Bass Publishers.

Burke, W. W. (2002), Organization Change: Theory and Practice, Thousand Oaks, Calif., Sage Publications.

Charih M., Paquin M., (1993), «La planification stratégique à Ottawa et Quebec : une comparaison de quelques ministères», Canadian Public Administration, Vol 36, Issue 2, p175-189.

Damanpour F., Schneider. M. (2006), "Phases of the Adoption of Innovation in Organizations: Effects of Environment", Organization and top Managers", British journal of Management, Vol.17, p. 215236.

Damanpour F., Schneider. M. (2008), "Characteristics of Innovation and Innovation Adoption in Public Organizations: Assessing the Role of Managers", Journal of Public Administration Research and Theory, Vol.19, Issue 3, p. 495-522.

DiMaggio P.J., Powell W.W. (1983), "The Iron cage Revisited: Institutional Isomorphism and Collective Rationality in Organizational Fields ", American Sociological Review, Vol. 48, Issue 2, p. 147-160.

Eisenhardt K M., (1989), "Building Theories from Case Study Research", The Academy of Management Review, Vol. 14, Issue 4, p. 532-550.

Elenkov, D. S., Judge, M., Wright, P. (2005), "Strategic Leadership and Executive Innovation Influence: An International MultiCluster Comparativ Study”, Strategic Management Journal, Vol. 26, Issue 7, p. 665-682.

Fernandez S., Rainey HG. (2006), " Managing Successful Organizational Change in Public Sector”, Public Administration Review, vol. 66, Issue 2, p. 168-176.

Fernandez-Alles M.D.L., Llamas-Sanchez R. (2008), "The neo-institutional analysis of change in public services" Journal of Change Management, Vol. 8, Issue 1, p.3-20.

Johansson T, Siverbo S. (2009), "Explaining the Utilization of Relative Performance Evaluation in Local Government: a Multi-Theoretical Study Using Data from Sweden", Financial Accountability \& Management, Vol 25, Issue 2, p. 197-224.

Kavanagh,M, Ashkanasy, N. (2006), "Management Strategy on Organizational Culture and Individual Acceptance of Change during a Merger", British Journal of Management, Vol. 17, p. 81-103.

Kemp E.J., Funk R.J., Eadie D.C. (1993), "Change in Chewable Bites: Applying Strategic Management at EEOC, Public Administration Review, Vol. 53, Issue 2, p. 129-134.

Lancer Julnes P. (2008), "Performance-Based Management Systems- Effective Implementation and Maintenance", Public Administration and Public Policy, CRC Press. 
Lancer Julnes P., Holzer M. (2001), "Promoting the Utilization of Performance Measures in Public Organizations: an Empirical Study of Factors Affecting Adoption and Implementation", Public Administration Review, Vol. 61 Issue 6, p. 693-70.

Lindblom C.E. (1968), The Policy Making Process, Prentice-Hall.

Maurel C. (2006), «Etude d'un changement organisationnel dans de grandes collectivités territoriales : l'évolution de la fonction contrôle de gestion», Finances Contrôle Stratégie, Vol.9, Issue 3, p. 105-134.

Michael Huberman M., Miles M B. (2002), The Qualitative Researcher's Companion, Thousand Oaks: Sage.

Moynihan D P. (2006), "Managing for Results in State Government: Evaluating a Decade of Reform », Public Administration Review, Vol. 66, Issue 1, p. 78-90.

Moynihan D. P. (2004), "Why and How Do State Governments Adopt and Implement 'Managing for Results' Reforms?", Journal of Public Administration Research and Theory, Vol. 15, Issue 2, p.219243.

Nutt P. C., Backoff, R.N. (1992), Strategic Management of Public and Third Sector Organisations, Josey-Bass Publishers.

Nystrom P.C., Ramamurthy K, A.L. Wilson A. L. (2002). "Organizational Context, Climate and Innovativeness: Adoption of Imaging Technology”. Journal of Engineering and Technology Management, Vol 19, Issues 3-4, p.221-47.

OCDE (2005), Modernising Government: The Way Forward, Paris.

Rusaw AC. (2007), "Changing Public Organizations: Four approaches”, International Journal of Public Administration, vol. 3, Issue 3, p. 347-361.

Scott W. R. (2001), Institutions and organizations Thousands Oaks, CA: Sage Publications.

Toulouse, J.M. (2007), Rapport de recherche sur la gouvernance des institutions universitaires. Rapport pour l'Institut sur la gouvernance des organisations privées et publiques (IGOPP-HEC), Groupe de travail sur la gouvernance des universités.

Walker R. (2006), "Innovation Type and Diffusion: An Empirical Analysis of local Government”, Public Administration, Vol. 84, Issue 2, p. 311-335.

Yang K., Hsieh J. Y. (2007), "Managerial Effectiveness of Governance performance Measurement: Testing a Middle-range Model", Public Administration Review, Vol. 67, Issue 5, p.861-878.

Yin, R. (1994), Case study research: Design and methods (2nd ed.). Thousand Oaks, CA: Sage Publishing. 


\section{Appendix 1}

Generic categories and sub-categories of the framework for the thematic analysis of content

\begin{tabular}{ll}
\hline Generic categories & Main sub-categories \\
\hline \multirow{2}{*}{ Triggering factors } & External events (imposed change) \\
Internal events (imposed change) \\
Individual factors (voluntary change) \\
Favorable socio-political environment \\
Economic context \\
Regulatory or emulative pressures \\
Implementation and institutionalization factors \\
Organizational and methodological factors \\
Managerial factors \\
Individual, leadership factors \\
External factors \\
Resistance factors \\
Local socio-economic and political climate \\
\\
Planned, deliberate \\
Emergent, gradual \\
Top-down/bottom-up \\
Process of experimentation and learning \\
Flexibility: content and processes \\
\\
Nature of change \\
Planning tools \\
Accountability tools \\
Evaluation tools \\
\hline
\end{tabular}




\section{Appendix 2}

\section{Actors interviewed}

\begin{tabular}{|c|c|c|}
\hline Local authority studied & Function of person interviewed & Duration \\
\hline \multirow{5}{*}{ GC Alpha } & Director General of Services & 2 hour \\
\hline & Head of Town Planning (politician) & 1 hour \\
\hline & Management Controller & 1 hour 30 \\
\hline & Chief Financial Manager & 3 hours \\
\hline & Head of Appraisal and Training & 2 hours \\
\hline \multirow{4}{*}{ GC Beta } & Director General of Services & 1 hour \\
\hline & $\begin{array}{l}\text { Deputy Head of Management Control and } \\
\text { Finance }\end{array}$ & 1 hour 30 \\
\hline & Management Controller & 3 hours \\
\hline & Chief Financial Manager & 2 hours \\
\hline \multirow{7}{*}{ Town Gamma } & Director General of Services & 1 hour \\
\hline & Deputy Director General of Services & 2 hours \\
\hline & Head of Transportation (politician) & 45 minutes \\
\hline & Head of Performance Management Initiative & 2 hours \\
\hline & Chief Financial Manager & 1 hour \\
\hline & Deputy Head of Community Affairs & 3 hours \\
\hline & Head of Parks and Gardens Department & 2 hours \\
\hline
\end{tabular}

